\title{
Redaksioneel
}

\section{Waarom ons in Afrikaans moet publiseer}

In 1975 het dr. C. v.d. M. Brink, 'n voormalige voorsitter van die Akademie, die stelling gemaak, "dat Afrikaans wat skaars 'n halwe eeu erkenning as landstaal geniet, hom in dié kort tydsbestek baie deeglik laat geld het as omgangstaal in die wetenskap en tegniek".!

Die afgelope tien jaar het die wetenskap en tegniek baie gevorder en nuwe terminologie moet gedurig geskep word. Vir Afrikaans om sy posisie te handhaaf in die wetenskap en tegniek wat sowel omgangstaal as doseertaal aan universiteite, tegnikons en skole betref, is dit noodsaaklik dat navorsings- en oorsigartikels in Afrikaans gepubliseer word. Geskikte navorsingstydskrifte is tans beskikbaar vir basiese en toegepaste natuurwetenskappe en die tegnologie. Dit word aanvaar dat u u beste navorsingsresultate in die wêreld se wetenskaptaal, Engels, wil publiseer. U moedertaal is seker geregtig op enkele navorsingsartikels, maar die publikasie van oorsigartikels in Afrikaans is seker $u$ plig. $U$ is die vakman en kan dit die beste doen!

Die Suid-Afrikaanse Tydskrif vir Natuurwetenskap en Tegnologie probeer 'n hoë standaard te handhaaf. Met $u$ ondersteuning kan ons beter doen.

Die skrywe van wetenskapartikels is harde werk, maar $u$ opoffering sal ' $n$ belegging wees in Afrikaans en hom in staat stel om homself te kan bly handhaaf as omgangs- en geskrewe taal in die wetenskap en tegniek!

A. Strasheim

\section{VERWYSING}

1. Brink, C. v.d. M. (1975). Waarom sou wetenskaplikes in Afrikaans publiseer? In Afrikaans: dit is ons erns, referatebundel: jaarvergadering van die Suid-Afrikaanse Akademie vir Wetenskap en Kuns, 24-26 Junie 1975, p. 28.

\section{Termomskrywings}

Omdat outeurs nie altyd weet wat met die terme navorsingsbrief, navorsingsartikel en oorsigartikel bedoel word nie, word hier 'n kort omskrywing van hierdie terme gegee:

- 'n Navorsingsbrief is 'n kort bekendstelling van navorsing waarmee die outeur besig is, of wat pas afgehandel is. Dit kan 'n uitgebreide navorsingsartikel oor die betrokke onderwerp voorafgaan. Ons vestig u aandag op voorbeelde in Nature en in hierdie tydskrif.

- 'n Navorsingsartikel behandel 'n meer uitgebreide en afgeronde stuk navorsingswerk en sluit 'n kritiese bespreking van die resultate in.

- 'n Oorsigartikel is 'n kritiese verslag van navorsing en kundigheid in 'n gespesialiseerde gebied, gerig op vakgenote. 